\title{
An Overview of Green Buildings Potential in Palestine
}

\author{
Nour Said, Husain Alsamamra* \\ Renewable Energy and Sustainability Program, Al-Quds University, Jerusalem, Palestine \\ Email address: \\ engnoursaid@gmail.com (N, Said),hsamamra@staff.alquds.edu (H. Alsamamra) \\ ${ }^{*}$ Corresponding author
}

To cite this article:

Nour Said, Husain Alsamamra. An Overview of Green Buildings Potential in Palestine. International Journal of Sustainable and Green Energy. Vol. 8, No. 2, 2019, pp. 20-33. doi: 10.11648/j.ijrse.20190802.11

Received: May 18, 2019; Accepted: June 18, 2019; Published: July 1, 2019

\begin{abstract}
Palestine is a developing country of a different nature from that of the developing countries of the world. It is a state under occupation that does not have many natural resources. It is prohibited from exploiting its natural resources such as water, salt, and natural gas, and even producing or importing electricity, occupation is the total importer of fossil fuels, adding $87 \%$ of its electricity needs. The design of green energy-saving buildings, combined with the exploitation of renewable energy resources, especially solar energy, with 3000 sunshine a year and an average of solar radiation of $5.4 \mathrm{~kW} \mathrm{~h} / \mathrm{m}^{2} / \mathrm{day}$, may be the only way out of the current situation. The main objective of this work is to provide a review of the green building sector in Palestine in terms of research issued, governmental and non-governmental bodies concerned with the development of this field, in addition to the most important projects implemented as green building in Palestine, and finally discussing the most important obstacles hindering the adoption of green building as a long-term sustainable development strategy. Our urban heritage has an architectural and construction style that meets the requirements of sustainable construction. However, the rapid and dramatic change in the construction sector, in terms of building materials and construction, has increased the energy burden. Throughout Palestine there are seven climatic zones, which in itself is a challenge to the design of green construction, in addition to low public awareness of the concept of sustainable construction. The study concluded that, the absence of legislations and laws binding the minimum requirements of green building are among the most important obstacles to the adoption of sustainable construction as a long-term strategy to achieve the desired independence in the energy sector, in addition to the non-use of financial tools to stimulate investment in the green building sector in Palestine.
\end{abstract}

Keywords: Palestine, Green Building, Climatic Zones, Natural Resources, Sustainable Development, Building Materials, Construction Sector

\section{Introduction}

The world population will reach 9 billion by the end of 2050 [1], this global population will be directly proportional to the demand for all components of life, water, and natural resources, which in turn will worsen the state of ecosystems around the world. For more than 20 years, the United Nations General Assembly has sounded the alarm, to set up a global scale aimed at achieving strategies related to long-term environmental issues, in response to this call, the Portland Committee held on March 20, 1987, which defined sustainable development as our ability to meet our immediate needs, without affecting the needs of future generations [2]. $50 \%$ of the world's population is in cities, $60 \%$ of the global population growth will occur within cities, until the end of
2030. Although the proportion of cities to the Earth's surface is less than $1 \%$ but is directly responsible for climate change now. Cities are the black hole for global energy, swallowing 75 percent of the world's total energy, and will, therefore, be the world's top greenhouse gas emitters. Recent studies show that more than half of the possibilities of reduction located inside buildings. Building green buildings are one of the most effective ways to reduce carbon emissions within cities [3].

The construction sector ranks first as a single contributor to carbon dioxide emissions and about two-thirds of global energy consumption occurs in buildings, according to a report by the United Nations Environment Program (UNEP) [1], the report noted that we have a great opportunity to use resources effectively in the construction sector. In keeping with the concept of sustainable development, the green building has the greatest potential to be a solution to reduce 
carbon emissions and stop the depletion of natural resources. Taking into account the economic dimension of sustainability is one of the fundamentals of the design of the green building. Therefore, there are many fruits that are collected and are usually evaluated from the angle of the building life cycle. In the 1970s, when the oil crisis emerged, the concept of green buildings appeared for the first time, and attention continued to this day. Include the concept of building on the agenda of the Stockholm Conference [4].

It argued that energy saving in the green building is between $25 \%$ and $70 \%$ [5-10]. Although there are those who argue that the performance of these buildings is not as planned [11-16]. Despite the global trend towards green buildings that achieve sustainability, we do not deny the fact that there is a lack of awareness about green building. In addition, building owners are not paying attention to the future and operational costs of buildings, this is one of the most important difficulties facing the spread of green building globally. [1, 17, 19-22]. Low water consumption and other natural resources, improved public health, increased productivity and improved indoor air quality $[17,18]$, are all side effects of the green building. If we want to define the green building, it is a basic design based on raising the efficiency of the use of resources, taking into account the minimum impact on human health and the surrounding environment during the life cycle, all this is done through sequential operations starting with the location of the building and ending with removal through construction Operation, maintenance, and recycling. Green buildings have many tangible, measurable and intangible effects on the environment and man. The low level of energy and water consumption is a measurable effect from the first day of construction of the green building, where water savings can be $30-50 \%$ and $20-30 \%$ savings in energy consumption. The quality of the ventilation, the comfort of the heat, the healthy atmosphere, the well-being, and the light are all benefits that the inhabitant feels from the first day [3]. Green construction or sustainable construction are two sides of a single coin [23]. They both represent a new concept for the construction industry, which is to increase the efficiency of the building, consume energy and rationalize the consumption of construction, and the building's relevance to the surrounding environment with the least damage and all this is reflected on the human health and well-being [24].

Dwaikat and Ali (2016), mentioned that there are many aspects and environmental considerations that must be taken into account during the construction, operation, recycling and disposal of waste for a green or sustainable building [25]. There was a need for general systems and measures to evaluate the green building, but there is no unified global system to evaluate the performance of the green building. Many countries around the world have developed their own systems and tools, this is known as building environmental assessment methods (BEAM) [26, 27]. Britain depends (BREEAM) The British Research Establishment Environmental Assessment Method, while United States adopts (LEED) the American Leadership in Energy and
Environmental Buildings, it is a globally recognized system widely deployed in several countries.

To sum up, the benefits of a green building cover three key aspects: economic, environmental and social, and this is what sustainability is all about $[28,29]$. The fans of the Green Building always emphasize the superiority of the green building on that non-green [25], For example, Madew [30] said that in the green building, energy saving and water drainage can reach $60 \%$, while Torcellini et al. [31] found that the performance of six green buildings offered between $25 \%-75 \%$ compared with other buildings which applied to energy law in the United States, Ries et al. [32] found that in a Manufacturing facility established as a green building certified by LEED, the efficiency of the building in energy use increased by $30 \%$, while productivity increased by $25 \%$.

In Palestine, which is divided into two geographical areas where communication is almost non-existent: the West Bank with a population of 2, 881, 687 people, according to the Palestinian Central Bureau of Statistics (PCBS), and the Gaza Strip with a population of $1,899,291$ people, with total population density 794 people $/ \mathrm{km}^{2}$, the most important thing is political instability, which in turn has severe repercussions on all sectors, including the energy sector and the local economy. The current political situation has made control of natural resources, including energy and water, impossible and complicated. As a result of this bitter reality, interest has grown in the concept of green buildings and the concept of sustainable alternative energy, which can be a radical solution to the situation of the deteriorating energy in Palestine in general. [33]

The lack of exploitation of renewable energy resources in Palestine, despite indicators of availability, inevitably increases the operating cost of buildings, depletion of energy resources in addition to increasing carbon emissions. Solar energy, wind energy, and geothermal energy, if used effectively in the green building design process, will provide a radical solution to the regulation of energy depletion, as well as achieve the desired independence in the energy sector in Palestine. Although there are many successful experiments to establish green buildings in Palestine, it is very necessary to conduct investigations in a systematic manner to know the shape and role of the future Palestinian home, which depends entirely on renewable sources of energy [33].

The possibility of free open trade to import the needs of Palestine from the petroleum products is negligible because Israel controls the oil imports in general, and therefore all the needs of Palestine are imported from the petroleum products and electric power through Israel, [34] In addition to considering Palestine as a total importer of petroleum products. All of the foregoing raises the complexity of the issue of safety in the energy sector in Palestine [33].

The exact date of the beginning of the interest of the Palestinian engineers in the green building is not known, but it is certain that there are several attempts to write about this subject through conferences or thesis on postgraduate studies. There are some reviews of previous studies related to green building in Palestine.

In 2010, Haj Hussain [35], discussed the possibility of 
adopting the concept of the courtyard in Palestinian homes as a future sustainable strategy, the author argued that the traditional Palestinian architectural model is an example of buildings adapted to the Palestinian environment and culture. The concept of the courtyard is, therefore, an element that can be reintegrated into the future Palestinian housing for sustainability and green building.

Salameh [36], focused on one element of the building, the external walls, as the building envelope responsible for energy conservation and making the building more efficient and sustainable, the writer said that the building systems in Palestine do not follow the strategy of sustainability, which increases the cost of operating the building. On the other hand, In 2013, Abdel Hadi [37], discussed the possibility of developing green residential buildings in the Palestinian cities, highlighting the necessity of developing residential buildings in Palestine in accordance with climatic and environmental developments, using alternative renewable energy technologies and reducing the heat load inside the buildings, taking into account the traditional techniques of Palestinian architecture within New technology. Abdel Hadi (2013) studied the traditional buildings in Palestine and identify the environmental elements, and methods used to suit the environment and the surrounding climate. She also went on to study possible ways to modernize building elements in residential buildings within a modern technology suitable for environmental conditions. And studied how to use modern technology to integrate the environmental dimension of residential buildings in the design decisions of the comprehensive data for the stage of design and implementation, and the operation of methods and techniques developed. The author concluded that the old buildings were enjoying a better climatic environment than the modern buildings for a number of reasons, the most important of which are: Heat insulation, steering, shading, and ventilation. She explained that investment in the previous elements increases the initial cost of the building, but the environmental, physical and thermal satisfaction will be much better than the initial cost. And recommended the need to develop building materials to make homemade materials with better characteristics than is currently available.

The schools were the focus of the author's research in 2016, Haj Hussain et al. [38], as they sought to evaluate the thermal comfort and energy performance, they went to study two samples in two different climatic zones, Nablus and Jericho. The writers concluded that the reality of schools in Palestine is far from the desired comfort in green construction. Energy needs improvements to reach the lowest level of energy consumption. The authors adopted two approaches to qualitative and quantitative research, linking the results of the two approaches, and producing the possible results that form the cornerstone for the design of green school buildings in Palestine. The paper was a part of a research project "Al-Maqdisi" that had been done during 2013-2015 and funded by the French government.

Al Atawneh et al. [34], as part of a Ph.D. thesis, which was being supervised by the Department of Architecture at the
University of Palermo. The writer discussed the obstacles and challenges facing the design of green buildings to a developing country such as Palestine. Al Atawneh divided the challenges into two main categories: organizational and technical difficulties. He also discussed regional experiences compared to Palestine. He also called on the writer to think of sustainable building materials as a future for palaces in Palestine and called for the employment of renewable energy as a future strategy for sustainability in Palestine.

Saadeh and Baba [39], as a part of the master's thesis for the writer, the question discussed in the paper is to what extent we stand by the application of green school building standards in Palestine and the future possibilities for achieving this. The study concluded that there are serious attempts by the Ministry of Education to improve the school building and its conformity with the green design standards of high efficiency through the application of some aspects and compliance with mandatory requirements, especially which can be applied within the possibilities of Simple financial possibilities.

Hodiri [4]. Based on the controversial issue of the actual economic performance of the Green Building compared to the expected performance of the building in theory, the writer investigated the truth by a case study, the school of (Aqqaba) as the first green school in Palestine, which received the golden classification of the Supreme Council of the Palestinian Green Building. The second objective was to compare the actual performance of the school in terms of water and energy expenditure compared to other government schools. The author used actual data for water and energy consumption for the Green School and compared it with actual reports of water and energy consumption for 205 public schools in the West Bank during 2016.

The main objective of this work is to highlight the green building in Palestine in terms of reality and achievements, the paper aims at highlighting the challenges facing the house design in Palestine as a developing country a study which is related to discussing different experiences in the field of energy saving strategies in Palestine and some surrounded countries, such as Jordan which shares certain climatic and architectural characteristics with Palestine. In summary, the paper makes a compressive overview of the green buildings in Palestine and how the availability of renewable energy can help to solve the situation of the energy sector in Palestine.

\section{Geographic and Demographic Description of Palestine}

Palestine lies on the western edge of the Asian continent, forming the south-west strip of the Levant, its length from north to south $430 \mathrm{~km}$, and the average width $80-70 \mathrm{~km}$. The geographical distribution of Palestine consists of two areas that are not geographically connected: the Gaza Strip and the West Bank, located between $3420^{\circ}-3530^{\circ}{ }^{\prime} E$ and 31 $10^{\circ}-3230^{\circ}{ }^{\prime} N$ as shown in Figure 1 below.

Despite the small area occupied by Palestine, it is a 
combination of elements of natural and human geography [40]. In the Jordan Valley, Palestine drops to 350 meters below sea level, where the lowest point in the world is formed, and it is leveled with the sea surface on the shores of Gaza and rises more than 1000 meters above sea level in some areas of the West Bank [41].
Palestine is classified in the Mediterranean climate, its summer is relatively long and dry, and its winter is very cold, with two distinct transitional periods, namely, spring and autumn, which are intertwined with the winter and summer seasons [42].

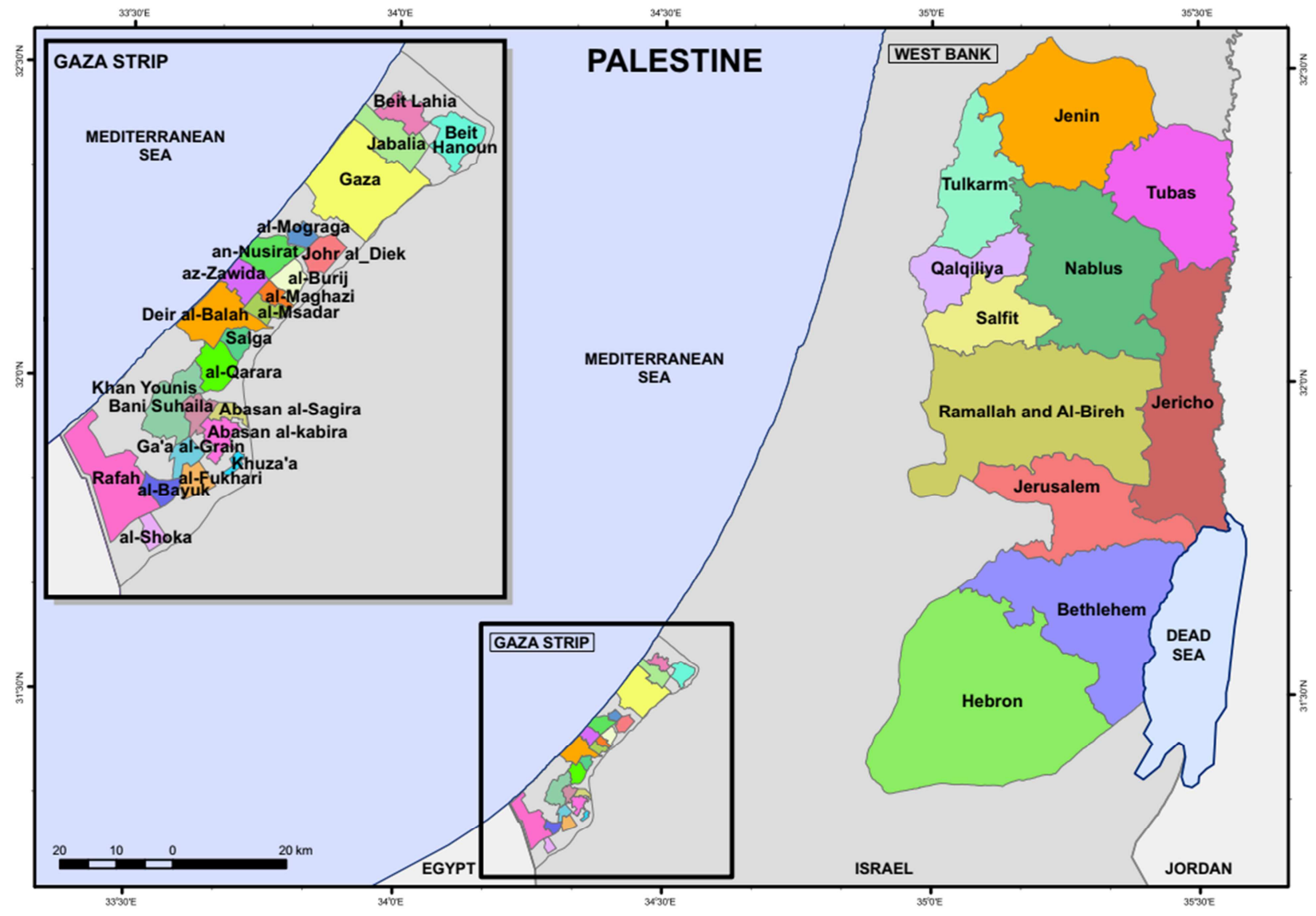

Figure 1. Map of the West Bank and Gaza, [33].

\section{Climatic Zones in Palestine}

When the Palestinian Ministry of Local Government decided to develop and adopt the energy-saving buildings code in Palestine with the support of the United Nations Development Program (UNDP), it was necessary to establish a classification of the climatic zones in Palestine. On this basis there was an agreement was reached on August 2002 between Applied Research Institute - Jerusalem (ARIJ) and (UNDP) [43].

The goal of the climate division of Palestine was to adapt and construct codes for energy-saving buildings in Palestine and thus was classified on several foundations such as average annual precipitation, annual temperature and humidity rate of the West Bank and Gaza.

Green building design is primarily based on energy efficiency and reduced cooling and heating loads. Climate analysis, which has a significant impact on energy consumption in buildings, is the cornerstone for adopting green buildings that achieve thermal comfort and energy efficiency. The report came out in five climatic zones in the
West Bank and two in the Gaza Strip.

Zone1: Occupies an area of $1103.3 \mathrm{~km}^{2}$, Hot and dry in summer, warm winter: This climatic zone extends along the eastern slopes, including the Dead Sea and part of the Jordan Valley, characterized by a hot and dry climate in summer and warm winter. Its cooling loads increase significantly in the summer.

Zone 2: This area is characterized by a hot, dry climate in the summer and mild winter, with area $823.2 \mathrm{~km}^{2}$ which extends along the eastern slopes of the West Bank.

Zone 3: It has a Mediterranean climate, a hot summer for half a year, and a mild winter, Stretching over $969.1 \mathrm{~km}^{2}$, of the entire area of the West Bank, a semi-arid region.

Zone 4: It features a warm, partly humid summer, cold winters, Mediterranean Sea climate approximately $47 \%$ of the total population of the West Bank lives on $1314.6 \mathrm{~km} 2$, Including Nablus, Jerusalem, Bethlehem, Ramallah, and AlBireh, it is considered to be the heart of the West Bank. It is inhabited by most of the buildings. The building materials are natural stone, concrete, concrete blocks.

Zone 5: Warm sub-humid summer, temperate winter - 
Mediterranean climate, the area covers an area of 1461.2 square meters, including Jenin, Tulkarm, Qalqiliya and Salfit as shown in Figure 2.

Gaza strip climate zones: Zone 6: This area covers the entire coastline and most of the northern, southern and central areas of the Gaza Strip, where more than $97 \%$ of the Gaza Strip's population lives. Its climate is humid, the average temperature is $18^{\circ} \mathrm{C}$.

Zone 7: An arid desert climate, inhabited by about $2.8 \%$ of the total population of the Gaza Strip.

It is clear that Palestine has many climatic zones, which means different temperatures, demographics, and different environmental conditions. This is a challenge to the design of the green building. Each climate zone has its own model [34]. Unfortunately, we would say that the majority of Palestinian designers and the public do not give enough attention to climatic zones and their impact on the design of a sustainable building.

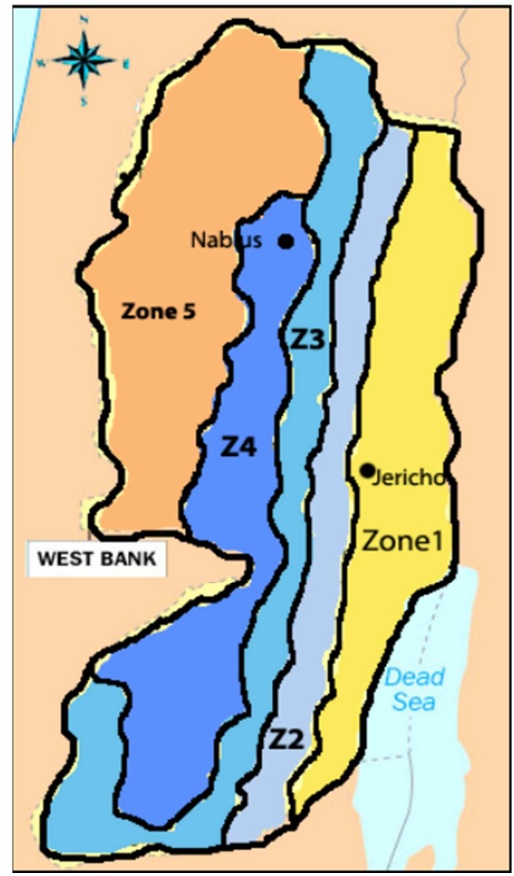

Figure 2. Climatic zones of the west bank-Palestine, [35].

\section{The Reality of Energy in Palestine}

The reality of energy in Palestine is deteriorating, Israel control of the Palestinian border and buffer limits the prospects for open trade of electricity and petroleum products and makes Israel able to impose non-competitive prices on energy tariffs in Palestine, crippling the ability to develop the energy sector. All petroleum products are imported by Israel [44], this difficult reality for a developing country such as Palestine makes renewables a radical solution to the independence and security of the energy sector in Palestine [45].

Abu Hamed et al. [46] stressed that the Palestinian citizen pays the most expensive price of energy compared to the surrounding area, in addition to the foggy national energy policy, and plans are an unclear strategy. In 2007, Abualkhair [47] studied the status of energy in Palestine in 1995, there were 65 areas in Palestine that do not have electricity, and the average consumption of Palestinian citizens in the West Bank and Gaza Strip is the lowest in the region. In $2012 \mathrm{Abu}$ Hamed et al. [46] concluded that the energy situation in Palestine was not better in 2007 , the citizen continues to pay the highest price for the lowest consumption rate by comparing with the region but the rate of consumption of electric power increased to $3808 \mathrm{GW} \mathrm{h}$ in the West Bank and $1606 \mathrm{GW}$ h in the Gaza Strip.

In 2016, Juiadi et al. [33] emphasized that the energy generated by petroleum products, electric power, and energy from renewable sources, including solar energy and wind energy, are the main pillars of the balance of the energy sector in Palestine, as noted in Figure 3. The writer said that Palestine imports all the needed oil derivatives. In 2013 the demand for energy in Palestine, for example, the residential, commercial and other sectors as the largest consumer of energy in Palestine were classified by $58.2 \%$, followed by the transport sector with $36.5 \%$, While the role of solar energy is limited to use in heating water by $65 \%$.

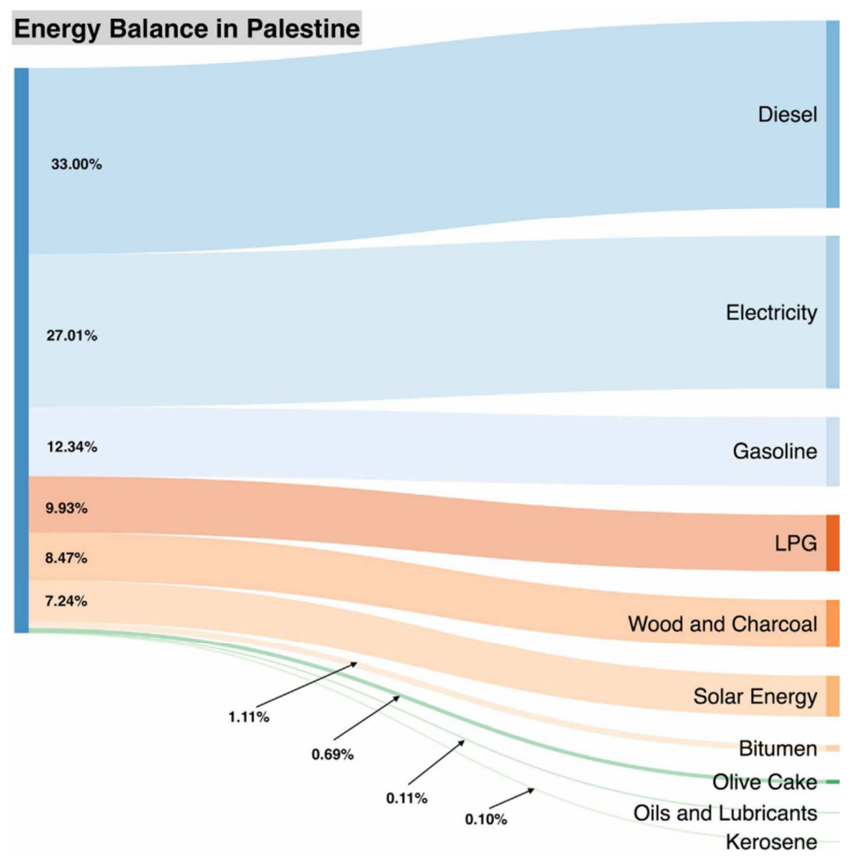

Figure 3. Energy balance in Palestine in 2016, [33].

\section{Renewable Energy Sources}

The political, economic and geographic conditions of Palestine make us always think of prioritizing renewable energy sources and their preference for fossil fuels, especially since Palestine is characterized by high indicators of the availability of renewable energy sources, mainly solar energy and wind power, as Palestine has more than 3000 hours of sunshine during the year [48].

The rate of solar energy in Palestine varies from $5.4 \mathrm{~kW}$ $\mathrm{h} / \mathrm{m}^{2} /$ day to $6 \mathrm{~kW} \mathrm{~h} / \mathrm{m}^{2} /$ day [49]. This energy is very 
promising if it is compared to other places in the world like Spain-Madrid (4.88 kW h/m²/day) [50], Australia -Sidney (4.64 kW h/m²/day) [51], Mexico-Gulf of Mexico (4.78 kW $\mathrm{h} / \mathrm{m}^{2} /$ day) [52].

Juiadi et al. [33], presented a complete review of the energy situation in Palestine. At the same time, the writer explained how renewable energy can play a key role in sustainable development and that it could be the magic solution for the Palestinian energy sector and its independence. And that one of the most important goals of the Palestinian government to generate $10 \%$ of the Palestinian market needs of electricity by renewable energy, by 2020. Solar energy is the most reliable source of renewable energy in Palestine, while not neglecting other sources such as wind power, geothermal energy, and biomass energy. Solar energy in Palestine is not properly exploited in the field of electricity production, although it is heavily exploited in domestic water heating. The treasure of solar energy in Palestine has 3000 sunshine a year and an average of solar radiation of $5.4 \mathrm{~kW} \mathrm{~h} / \mathrm{m}^{2} /$ day. Wind power in Palestine is moderate, can be used as supporting systems in remote speakers not connected to the electricity grid, while the speed of the wind in Gaza does not reach the level of power generation, it is very low, It can only be used as a water pump. Another obstacle to the exploitation of wind energy in Gaza is the difficulty of installing turbines. There are no open areas that are not populated.

There is an awareness of the importance of national sovereignty over energy in Palestine, and there is a deep understanding that renewable energy sources are the path to this sovereignty. The use of renewable energy to generate electricity in high-consumption sectors, as well as remote areas not connected to the electricity network, will significantly reduce our dependence on the production of electricity and increases the ability of Palestinians to establish sustainable development and reduce carbon emissions.

If we look at Figure 4, we will see the monthly solar radiation rate in 2010 for four cities representing the north, center, and south of the West Bank respectively: Salfeet and Tubas, Ramallah, Hebron. The solar radiation on the horizontal surface varies from $2.63 \mathrm{~kW} \mathrm{~h} / \mathrm{m}^{2} /$ day in December to $8.4 \mathrm{~kW} \mathrm{~h} / \mathrm{m}^{2} /$ day in June.

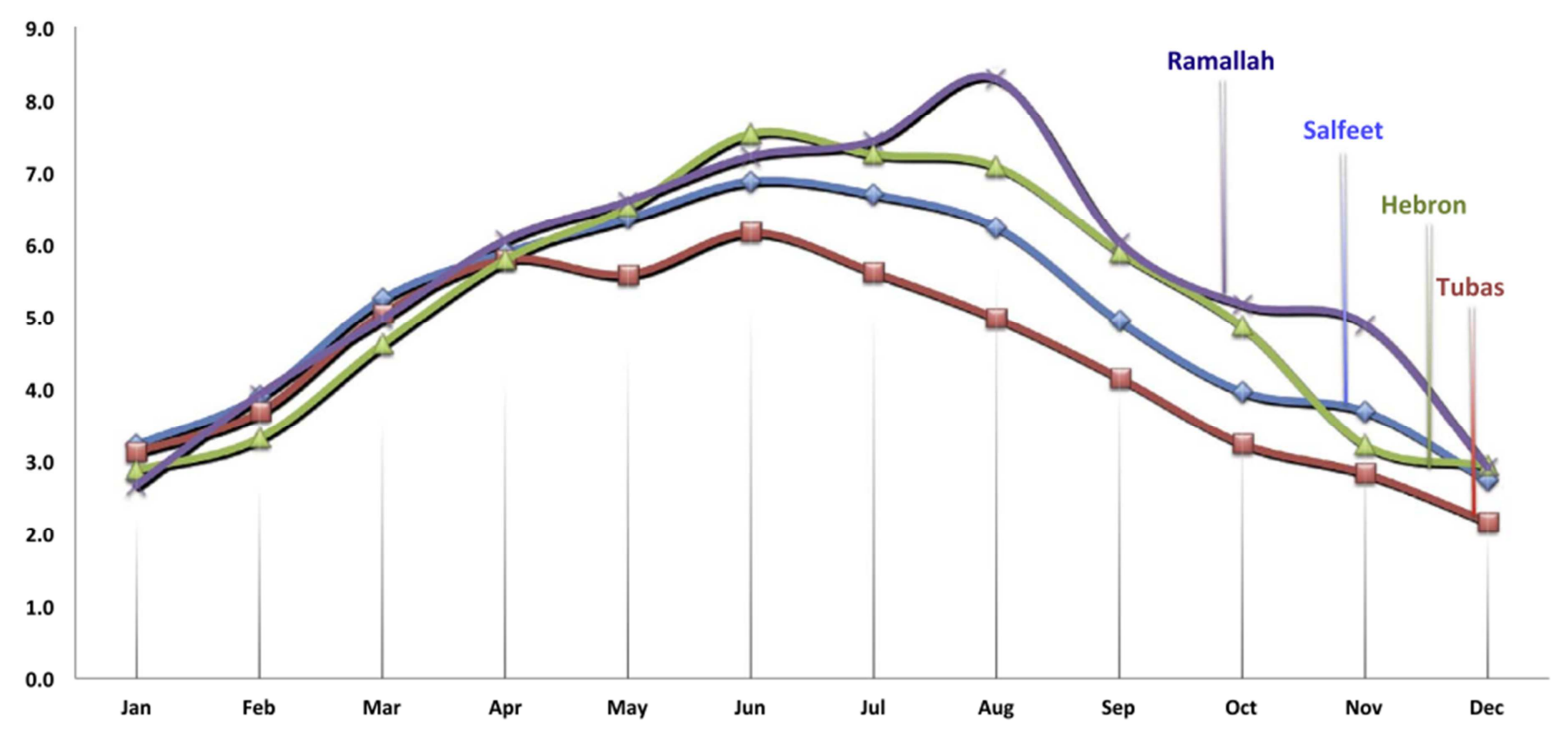

Figure 4. solar radiation for different cities in west bank by month, 2010, [33].

The above results seem encouraging to the use of solar energy in electricity generation on a large scale and economically feasible, especially areas away from the electrical grid to achieve self-reliance, and reduce carbon emissions compared to currently used diesel generators.

Interestingly, this abundant solar energy in Palestine is not incorporated into the design of buildings except in a very limited way, is almost nonexistent, for example (AbuHafeetha, 2009) [53], proved that the electrical energy consumption of 108 schools In Nablus city is $140 \mathrm{MWh} /$ year, This amount of energy is consumed by indoor lighting [38].

In conclusion, Palestine as a developing country and prohibited from exploiting its natural resources such as water, salt, and natural gas, and even producing or importing electricity. The design of green energy-saving buildings, combined with the exploitation of renewable energy resources, especially solar energy, is the only way out of the current situation [34].

\section{The Construction Sector in Palestine}

Sustainability is a broad and comprehensive concept based on many aspects, including social, economic, cultural and environmental [36]. Sustainable building is one of the most important elements of sustainable development, which has become the world's top priority. In Palestine, the construction sector is one of the largest sectors affecting economically, socially and environmentally. The sector directly affects the quality of the environment and energy during the construction, running and maintenance phase. According to 
the Palestinian Central Bureau of Statistics, in 2010 the construction sector recorded the highest growth rate of $36 \%$, in addition to the increase in the number of workers in this sector by $22 \%$ compared to 2009 [61]. In recent decades buildings have become more lethal to the environment and more depleted of natural resources, with much internal heat disturbance, resulting in increased cooling loads in the summer and winter heating loads. As a result, construction costs and consumption of fossil fuels have increased significantly, thus increasing carbon emissions. It's shocking to say that, many Palestinians build their own homes without recourse to an engineer, which increases random construction, in addition, the Palestinian public treats the building as a facility, not as a living space, which requires special attention to thermal comfort, good ventilation and natural lighting [34]. In the past, the Palestinian used building materials to suit the nature of his area. In other words, he created materials from the local environment that fit the region's climate. In fact, this is one element of sustainability. At present, all construction materials with different areas consist of: natural stone, concrete, concrete bricks, and some use thermal insulation layers which are not commonly used in Palestinian homes [34]. The natural stone itself is one of nature's inaccessible resources, so it's not permanent and the stages by which natural stone passes from extracting to manufacturing and even transport, are itself processes that hurt nature [36].

The Palestinian public does not pay much attention to heat insulation materials, because the high price increases the initial cost. This is one of the obstacles that prevent the spread of the use of insulation materials, thus increasing the load on energy to achieve the desired thermal comfort by installing air conditioning and cooling. Even if the insulation materials are used, it is used in a random manner that is not based on thermal calculations, and there is no consideration of the different climatic zones in Palestine.

In 2011, Salameh [36] Concluded that the system of building practice in Palestine does not take into account the concept of sustainability, and therefore the construction procedures in Palestine increase the complexity of the environment and raise the cost of operation and maintenance of the building. The writer said that the movement of people towards modern building materials because of the cheap price and aesthetic advantages and ease of implementation, regardless of the fundamental defects such as ease of heat loss or easy absorption of heat, which increased the building and the operational requirements, and the need for permanent maintenance. In addition, the construction sector's tendency to use new materials in the exterior of the building, such as metal and glass, has further undermined the sustainability of construction and limited attention to aesthetics regardless of the effectiveness of the materials. Construction in the West Bank is one of the most important pillars of the national economy. However, the dependence of this sector on the traditional machines and the manufacture of materials, in addition to the huge amount of waste resulting from the construction process, eliminates the concept of sustainability in this sector.

\section{Traditional Architecture and Modern Architecture in Palestine}

The raw materials used in construction are very diverse in Palestine and have played a major role in architecture since ancient times, in terms of resisting the factors of nature, climate, and the surrounding environment, and responding to the possibilities available and the function of construction, the variety of construction between stone, pottery. And how construction is considered essential to the study of traditional architecture in terms of building materials and the impact of climate and the surrounding environment which is considered very important. The traditional Palestinian architectural style has been able to adapt to the surrounding environment by simplifying construction methods and has great interaction with the surrounding environment. Thus, we can say that the traditional Palestinian architectural style applied the principles of sustainable green construction [34, 36, 37]. Abdel Hadi [37], Claimed that the old buildings had a climate environment and apply the conditions of sustainability more than that of modern for a number of reasons, the most important of which:

1. Better Heat insulation due to the use of clay as a building material in addition to the thickness of the large walls.

2. Shading where the thickness of the walls on the provision of shading in the summer, while can enter the sun in the winter because of the low rise of the sun throughout the day.

3. Orientation where it is clear that the historical buildings were sensitive to the orientation of the direction in the south.

4. In high humidity and coastal areas, people have been forced to construct individual buildings with no overcrowding to provide good ventilation. In mountainous areas, however, we find the direction of the adjacent construction, which reduces the heat loss in the winter.

Architecture moved a qualitative leap towards the end of the first half of the twentieth century was the outcome of the interaction of local environmental factors with the social and cultural factors, which varied from one place to another depending on the climate and surrounding nature and building materials available in the region.

In ancient construction, human beings took care of the local climatic conditions, such as the thickness of the walls, the size and height of the openings, in addition to the shape of roofs, and local building materials such as stone, Which was reflected by reducing the intensity of sunlight falling on the building, and characterized the surrounding streets that were narrow and winding.

The traditional architectural style in Palestine is distinguished by its energy-saving elements. For example, the inner courtyard provides thermal stability, providing 
natural ventilation and lighting, energy saving, and social benefits. There are other elements that characterize the traditional construction such as Iwan, hallway, wind catcher, Almashrabia and all contribute to energy saving. According to the Register of Historic Buildings in Palestine issued by the Riwaq Foundation, the random expansion witnessed by the Palestinian territories in the period 1995-2000 was the result of an unprecedented rate of construction. The percentage of buildings in some cities and villages reached $50 \%$ without Urban vision or planning [54].

At the beginning of the twentieth century, there were many changes in the pattern of construction in Palestine, which resulted from the change in the nature of life in terms of social and economic, and the entry of new building materials except for stone, which is still considered one of the basics of building materials. The change in the construction industry, especially building materials such as cement and iron, has radically changed the way of construction, such as reducing the thickness of walls and ceilings, and using more building materials to deliver heat, which increases the loss of winter and summer gain [37], but in new forms commensurate with the development of construction, Constructively functional and took a new form of materials exotic to our environment, and be so-called contemporary architecture. [36]

To summarize, Palestine, like other third world countries, suffers from the disadvantages of indiscriminate construction and non-compliance with building regulations, which resulted in a disregard for the standards and the depletion of green areas due to urban expansion. Most of the buildings in cities and villages were built without thermal insulation according to old specifications dating back to the 1950s and 1960s; While some Palestinian cities such as Ramallah face an accelerated construction cycle with new building methods and materials such as curtain walls; traditional construction systems were better, subject to environmental specifications, and some institutions Torah which have given the construction sector and housing a great interest such as:

1. The Supreme Palestinian Council for Green Building

2. CHF (Cooperative Housing Foundation)

3. Reviving Earth Architecture in Jordan valley -Palestine.

\section{Palestine Higher Green Building Council (PHGBC)}

The Palestinian Green Building Council, a nongovernmental organization with no legislative authority, has emerged from the cooperation between the Palestinian Engineers Association and several governmental and nongovernmental organizations. The Supreme Steering Committee formulated the general orientations of the Council, which included parties directly or indirectly related to the engineering work in Palestine. We mention: the Ministry of National Economy, the Ministry of Local Government, the Ministry of Health, the Ministry of National Economy, the Ministry of Education, the Ministry of Local Government, the Water Authority,, the Environmental
Quality Authority, the Energy Authority,, the Standards and Metrology Institution, Federation of Palestinian Industries, Representatives of Palestinian universities, the representative of Palestine in the Energy Committee of the Union of Arab Engineers, and the representative of Palestine in the Energy Committee of the International Federation of Engineering Organizations $[4,55]$.

Objectives of the Council:

1. Educating the community about the concept of green buildings.

2. Supporting research and studies in the field of green buildings and clean energy, and employing them in the process of promoting this sector in Palestine.

3. The Council provides necessary guidance on green buildings.

4. The Council works on training human resources to work in the field of green buildings through specialized development plans.

5. The Council provides funding for researchers and specialists in this field to prepare standards and research related to the development of green buildings in Palestine.

6. The Council issued a guide on green buildings in Palestine that is compatible with the country's climate, geographic and social specificities [55].

In 2013, the Palestinian Engineers Association, in collaboration with the Supreme Council of Green Buildings, issued a guidebook on green buildings in Palestine, in accordance with the geographical, demographic, climatic and other circumstances of Palestine. The guide book was a pioneering step towards a general framework for green building strategy and sustainability. The green council defined the green building as the building that achieves a balanced relationship between two parties, the occupants of the building and the surrounding environment. The guiding principle is that the most important principle of green building is its effective treatment with energy saving, integration with clean energy systems, lighting and natural ventilation, as well as the interaction of the building with the environment so that it is less environmentally during construction, maintenance, and housing. [4].

There are three axes in which the green building achieves the balance between man and the surrounding environment. The first axis is dealing with an energy effectively. The second axis depends on making the most of the environmental, geographical and climatic conditions. The last axis is sustainability. (PHGBC, 2013) [42].

The candidate buildings are evaluated as green buildings based on their collection points out of 200 points, the collection of points depends on the possibility of the building to collect points in six parts:

1. Sustainability of the construction site constitutes $15 \%$ of the total points.

2. Energy efficiency is $30 \%$ of the total points.

3. Water efficiency at a rate of $25 \%$ of the total points

4. $15 \%$ of the total points were for the quality of the internal environment 
5. $10 \%$ of the total points relate to materials and resources

6 . Innovation in green building design reaps $5 \%$ of total points

Accordingly, there are four categories based on the evaluation of green buildings in Palestine, as follows:

1. Diamond class buildings that get 160 points and more.

2. Gold category, which is between 140 and 159 points

3 . The Silver category is a building that scores between 120 and 139 points

4. Buildings with between 100 and 119 points are in the bronze category

No building shall be evaluated by the Supreme Council unless it complies with the minimum mandatory requirements:

1. The building must be used for at least 12 months before being evaluated on an operational and maintenance basis, with complete information on water and electricity consumption during this period.

2. The building must be committed to safety measures known locally and internationally, in addition to its commitment to local building policies [42].

\section{Palestinian Code, Energy Efficient Building Code, Ministry of Local Government, 2004}

The Ministry of Local Government issued this code to deal with the modern construction legislation, which works to reduce waste of energy, and the development of Palestinian building systems through the thermal design of the external elements of the building, and the protection of the environment in reducing the emission of waste gases, and ensuring the thermal satisfaction, and basic principles in the design of thermal buildings, Buffer and its properties [56].

To summarize, there are three main bodies cooperating in this field, the Supreme Council for the Green Building of the Palestinians, and the Engineers Union in cooperation with the Ministry of Local Government. The three parties are working hard to find a sustainable strategy for the construction of green buildings in Palestine, through a framework of wellconsidered policies.

\section{Green Buildings Projects in Palestine}

I. Palestinian Museum: When the Palestinian Museum opens its doors in the fall of 2014, visitors will be able to experience Palestine's first energy-efficient green building. Striving for a Leadership in Energy and Environmental Design (LEED) silver rating [57].

II. M. Qattan Foundation New Building: Qattan Foundation has established a new building in the city of Ramallah to serve as a multi-purpose cultural building with a total area of 7, 730 square meters. The building is the first registered building certified by the Palestinian Supreme Council for Green Buildings. The building includes several activities such as the library, a gallery, a multi-functional hall, a fine art studio, a theater, training rooms, classrooms, a restaurant and a studio for performing art $[55,58]$.

III. Shtayya green building: the building is under construction, and when completed, will be the first green residential building in Palestine, The Project's idea began in the middle of 2016 and after about a year we've got the building license from the related authorities in Palestine. We 've followed and applied the required Green \&Sustainable codes as requested according to LEED forms and regulations [59].

IV. Aqqaba Green School: it's considered as the first green school in Palestine is rated as Gold by the Palestinian Green Building Council. The site of the school in the village of Aqaba in Tubas province, which is hot and dry in the summer and the mild winter, with an average temperature of 18 degrees Celsius. The school opened in 2016, with a total area of 1408 square meters, accommodating 156 students. The school has seven classrooms, two labs and a library, as well as green spaces, three water wells, a gray water recycling system that is later used to irrigate crops, and a solar energy system to produce electricity $[4,55]$. We also recall Wadi Almogir school in Hebron, where it relied on the process of conditioning and cooling the health rooms on the fixed land energy through the work of concrete tunnels that transfer air to each classroom so that the weather is nice in summer.

V. There are serious attempts by the Ministry of Education to improve the school buildings and its conformity with highquality green design standards, through the application of certain mandatory aspects [39]. In addition to the Ministry of Energy has provided facilities on the use of solar cells to encourage their use on the roofs of homes [34, 38]. There are several individual projects to design buildings that achieve the concept of sustainability in Palestine. These buildings will be harmonious with the environment and provide comfort for the integration with clean energy sources. Hani Al Hassan, a Palestinian architect who designed an environmentally friendly house in Jericho as a leading individual effort to design sustainable homes suitable for the desert environment, Al Hassan has received an international award as a result of this project [34].

VI. ShamsArd Design Studio is committed to creating sustainable and green designs that emulate the environment and society and adapt to the surrounding climatic conditions. The studio is dedicated to the design and implementation of green projects, which are integrated with clean alternative energy solutions and waste recycling, Ventilation and natural lighting, the studio was founded in 2012 and its main headquarters in the city of Ramallah, has been implemented and designed several sustainable buildings, We mention Kaykab Ecology Museum, the building is located in the city of Ramallah, with a total area of 60 square meters. It was completed in 2012. The building was built on the basis of green buildings. It was built entirely of blocks made of the same site. The building is integrated with a passive solar system, collect solar heat and wind chimney as you see in Figure 5. Moon House, appears in Figure 6, the building is 84 square meters in size and is a private residence completed in 
2013. The building includes green building technologies such as solar energy and natural ventilation using what is known as stoves, a pattern of traditional architecture in Palestine, as well as water recycling Gray, and building materials from the local environment as well as finishes [60].

To sum up, there are about 1, 195, 848 residential buildings in Palestine according to the general census of 2017 [61], the number of green buildings of the total number almost does not mention, There are individual pilot attempts to build green buildings, but the Palestinian public does not have enough awareness or interest in the term green buildings as a way of living and integrating with nature, climate and energy sources.

Finally, what can be said, that Palestine does not have sufficient control over its natural resources, One of the basic rules of the Green Building is to use the available natural resources so that the Palestinians will find themselves forced to follow the principles of the Green Building during construction. This is done only by strict legislation and regulations with incentives for green building. A thousand miles start with the necessary laws, legislation, and awareness $[4,55]$.

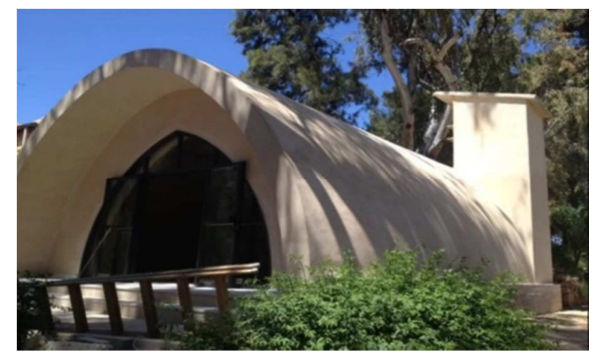

[Source: https://www.shamsard.com/architecture]

Figure 5. Kaykab Ecology Museum.

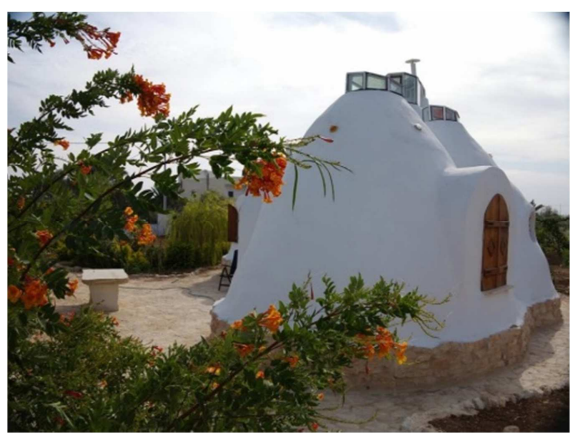

[Source: https://www.shamsard.com/architecture]

Figure 6. Moon house.

\section{Research Limitations}

Although we highlighted the current situation of the green building in Palestine, and this is the goal of the work from the beginning, but there were a lot of research parameters that prevented further expansion in the search:

a) The lack of studies in Palestine that contribute to the definition of green building concepts, energy-saving building systems and the risks of climatic predictions that have become clear, due to the increase in global warming [37].

b) The absence of standards for the design stages of the green building in Palestine helps the Owner or Contractor to make decisions during the design phase and to choose building systems and materials that appear to be simple and routine, but are in fact becoming very dangerous, directly affecting our environmental occupants. Health and economic [36].

c) Most of the studies available in traditional construction focused on the form of building and used building materials, and did not give sufficient attention to the building and its suitability to the surrounding environment.

Analysis of the Possibility of Adopting Sustainable Construction in Palestine as a Long-Term Strategy, Strengths, and Weaknesses

This analysis will determine our current position and our future direction within a long-term strategic framework. It is important to know that any strategic plan ready has succeeded in several countries around the world that may not fit Palestine, which is characterized by a very special situation. The promotion of the sustainable building sector is closely related to several areas including social, economic, political, cultural, technological, legal and environmental issues. This is an invitation to the decision makers to view this work as a reference that highlights the current state of the green building and approved its development and adoption as a national strategy contributing to the independence of the energy sector in Palestine.

I. Strengths

a) The attention of the Palestinian Government, the Energy Authority and the engineer's association to achieve a renaissance in this sector.

b) Access to alternative clean energy resources available in Palestine, such as solar, wind, biomass energy.

c) Take advantage of our cultural heritage, since traditional old buildings were more sustainable than modern ones, in terms of thermal insulation, shading, steering, and ventilation.

d) The possibility of benefiting from the Jordanian experience in the subject of green building, especially that Jordan shares with Palestine characteristics of climate, culture, technology and building materials [36].

II. Weaknesses and Challenges facing Palestine towards sustainable green building

B. Atawneh in 2015 [36], summarized the difficulties facing sustainable development buildings in Palestine:

The limited availability of financial support for green building projects in Palestine is a major obstacle for the Palestinians, especially with the high cost of some technological aspects in the energy-saving buildings. In addition, the low income of the Palestinian citizen makes him think of the lowest initial costs of building a building. And the concept of green building.

a) Absence of laws and legislation, there is no governmental regulatory framework to compel citizens to meet the minimum requirements of green buildings. There is no legislation by the municipalities and local 
councils that regulate the work of the requirements of the green building in Palestine, in addition to the absence of the awareness and guidance role in order to encourage the public, as many regulations around the world such as new California T-24, its goal is having all residential buildings to be green by 2020 , and all commercials by 2030 [63].

b) Lack of trained human resources, this is due to the very low number of qualified engineers who have learned the origins of green building design.

c) The Nature of building materials, In the past, the Palestinian used building materials to suit the nature of his area, in other words, he created materials from the local environment that fit the region's climate. In fact, this is one element of sustainability. At present, all construction materials with different areas consist of: natural stone, concrete, concrete bricks, and some use thermal insulation layers which are not commonly used in Palestinian homes.

The natural stone itself is one of nature's inaccessible resources, and thus it is a material that is not permanent [34], and the stages by which natural stone passes from extracting to manufacturing and even transport, are itself processes that hurt nature.

a) The lack of designers combining traditional architectural design techniques with energy efficient systems saves energy mainly on mechanical and electrical solutions that integrate architectural and structural design, so we need designers who have the skills to design a green energy-saving building.

b) The Palestinian public does not pay much attention to heat insulation materials, because the high price increases the initial cost. This is one of the obstacles that prevent the spread of the use of insulation materials, thus increasing the load on energy to achieve the desired thermal comfort by installing air conditioning and cooling.

Even if the insulation materials are used, it is used in a random manner that is not based on thermal calculations, and there is no consideration of the different climatic zones in Palestine

a) Few designers or people pay attention to the different climatic zones in Palestine, and this in itself is one of the most important obstacles to the existence of designs to build energy conserves and adapts to the surrounding environment.

Along the West Bank, there are 5 climatic zones, and two in Gaza. This means that there is a new challenge in designing green buildings. Every climate zone has its own design and building materials that suit it.

b) There is no mandatory legislation on the use of thermal insulation, which cost millions of dollars.

\section{Conclusions}

This work presented a long review of the green building sector in Palestine in terms of the research carried out in this field, the projects that were implemented, the institutions that were interested in developing this sector, in addition to the most important achievements.

Let us agree that there is a keen interest from the government, the Engineers Syndicate, the Ministry of Local Government and the Supreme Council for Green Building, in the sense of the sustainability of the buildings in Palestine and that there is full awareness among these parties that the green building combined with the abundance of clean energy sources in Palestine is a big step towards the independence of the energy sector.

But If we ask the following question: What percentage of housing units established in 2017 in the West Bank and Gaza Strip according to green construction standards and specifications? The ratio is very marginal, almost zero, although the risk inherent in financing the green building market is marginal, given the expected future savings. In recent decades, tens of thousands of buildings have been built in the West Bank and Gaza Strip, without taking into consideration the specifications of green building and thermal insulation. Many people avoid providing quality environmental insulation in buildings, claiming to be costly. Palestinian, we can say that the culture of construction is characterized by excessive waste; buildings and apartments are adopted in a completely inefficient way. The Palestinian construction sector is very conservative and it is difficult to introduce new technologies that have gained momentum all over the world.

The Palestinian Authority areas lag behind many others. It is common for the world to bridge the gap between relatively high initial investment in sustainable construction on the one hand and future financial savings and benefits on the other, through the use of various financial instruments provided by public and private sector financing. These include facilities and financial exemptions, loans for government bailouts and improved green leases, as part of government plans, as well as "green" loans for the renovation of properties and houses granted by commercial banks during the buying and selling process. The question is: Why do not attractive financial instruments that are applicable to green building encourage us to change this reality? First, it must be agreed that green construction involves not only financial savings and environmental service; its advantage is that it requires more serious planning and stronger cooperation among all those involved in the construction process.

As green architecture is voluntary and non-binding, economic incentives including tax cuts on green goods, subsidies and soft loans for green building, support for energy-saving systems, and the private sector initiative to provide incentives such as green building insurance, and to give preference in housing loans to green buildings. In short, the first step towards a sustainable and independent future in Palestine is the laws and legislation that are binding on the conditions of sustainability in buildings, in addition to activating financial instruments that stimulate the private sector to invest in green building, in addition to raising public awareness of the economic and health benefits of the Palestinian people. The current situation will not be 
overnight in Palestine, but there is always a first step in the march of a thousand miles.

\section{Acknowledgements}

The authors would like to acknowledge: Dr. Luay N. Dwaikat (Building Engineering Dpt. An-Najah University), Dr. Muhannad Haj Hussian (Building Engineering Dpt. AnNajah University), Dr. Bader Alatawneh (Architecture, Dpt. Palestine Polytechnic University PPU), Dr. Mutasem Baba (Building Engineering Dpt. An-Najah University), Miss Haneen D. Sharif (Palestine Green Building Council (PGBC ((Eng. Ahmad Shtayyah (SHTAYYA for sustainable architecture Office).

\section{References}

[1] UNEP, Towards a Green Economy: Pathways to Sustainable Development and Poverty Eradication, United Nations Environment Program (UNEP), 2011 https://sustainabledevelopment.un.org/index.php?page=view\& type $=400 \& n r=126 \&$ menu $=35$

[2] Brundtland G. H, Report of World Commission on Environment and Development (WCED): Our Common Future, A Report Prepared for the General Assembly of the United Nations, United Nations, 1987 http://www.undocuments.net/our-common-future.pdf

[3] Kubba S. Handbook of green building design and construction, Sam Kubba, 2012. https://www.sciencedirect.com/book/9780123851284/handboo k-of-green-building-design-and-construction\#bbook-info

[4] Hodiri H. Assessing the Actual Performance of Green Buildings in Palestine: A Case Study (Master Thesis) Nablus, Palestine: An-Najah National University; 2018. https://repository.najah.edu/handle/20.500.11888/14171

[5] Yudelson J. The Green Building Revolution; Island Press: Washington, DC, USA, 2008

[6] Ries R, Bilec M. M, Needy K. L, Gokhan N. M. The Economic Benefits of Green Buildings: A Comprehensive Case Study. Eng. Econ. 2006, 51, 259-295.

[7] GSA Public Buildings Service. Assessing Building Performance: A Post Occupancy Evaluation of 12 GSA Buildings Research; GSA Public Buildings Service, 2008. https://www.gsa.gov/cdnstatic/GSA_AssessGreen_white_pape r.pdf

[8] Kats G. Green Building Costs and Financial Benefits; Massachusetts Technology Collaborative: Boston, MA, USA, 2003.

[9] Kats G. Greening Our Built World: Costs, Benefits, and Strategies; Island Press: Washington, DC, USA, 2010.

[10] Torcellini P, Pless S, Deru M, Griffith B, Long N, Judkoff R. Lessons Learned from Case Studies of Six HighPerformance Buildings; Technical Report NREL/TP-55037542. National Renewable Energy Laboratory (NREL): Golden, CO, USA, 2006.

https://www.nrel.gov/docs/fy06osti/37542.pdf
[11] Menezes A. C, Cripps A, Bouchlaghem D, Buswell R. Predicted vs. actual energy performance of non-domestic buildings: Using post-occupancy evaluation data to reduce the performance gap. Appl. Energy 2012, 97, 355-364. https://www.sciencedirect.com/science/article/pii/S030626191 1007811?via\%3Dihub

[12] De Wilde P. The gap between predicted and measured energy performance of buildings: A framework for investigation. Autom. Constr. 2014, 41, 40-49. https://www.sciencedirect.com/science/article/pii/S092658051 400034X?via\%3Dihub

[13] USGBC Research Committee. A National Green Building Research Agenda; U.S. Green Building Council, 2008; Available online:

https://www.usgbc.org/drupal/legacy/usgbc/docs/Archive/Gen eral/Docs3402.pdf

[14] Burnett J. Costs and Benefits of Building Commissioning. Hong Kong Inst. Eng. Trans. 2008, 15, 9-16.

[15] Cohen R, Standeven M, Bordass B, Leaman A. Assessing building performance in use 1: The Probe process. Build. Res. Inf. 2001, 29, 85-102. https://www.tandfonline.com/doi/abs/10.1080/0961321001000 8018

[16] Bordass B, Cohen R, Standeven M, Leaman A. Assessing Building Performance in Use 3: Energy Performance of the Probe Buildings. Build. Res. Inf. 2001, 29 , 114128.https://www.tandfonline.com/doi/abs/10.1080/096132 10010008036

[17] Kats, G.; Alevantis, L.; Berman, A.; Mills, E.; Perlman, J. The Costs and Financial Benefits of Green Buildings. A Report to California's Sustainable Building Task Force; U.S. Green Building Council, 2003; https://www.usgbc.org/drupal/legacy/usgbc/docs/News/News4 77.pdf

[18] Yudelson J. Green Building A to Z: Understanding the Language of Green Building; New Society Publishers: Gabriola Islands, BC, Canada, 2007. https://scholar.google.com/scholar lookup?title=The\%20Gree $\mathrm{n} \% 20$ Building\%20Revolution\&author=J.\%20Yudelson\&publi cation_year $=2008$

[19] Choi C. removing market barriers to green development: principles and action projects to promote widespread adoption of green development practices, J. Sustain. Real Estate 1 (2009) 107-138. https://www.scopus.com/home.uri URL: http://www.josre.org/wp-content/uploads/2009/12/removingmarket-barriers-to-green-development-principles-and-actionprojects-to-promote-widespread-adoption-of-greendevelopment-practices. pdf

[20] Bowman R., Wills J. Valuing Green: How Green Buildings Affect Property Values and Getting Valuation Method Right, Green Building Council of Australia, Sydney, 2008 https://www.gbca.org.au/docs/NSC0009_ValuingGreen.pdf

[21] UNEP, Guidelines on Education Policy for Sustainable Built Environments, United Nations Environment Program (UNEP), 2010, https://wedocs.unep.org/bitstream/handle/20.500.11822/7997/Guidelines\%20on\%20Education\%20Policy\%20for\%20Sustai nable $\% 20$ Built $\% 20$ Environments2010993.pdf? sequence $=3 \&$ is Allowed $=y$ 
[22] Helgeson J. F, Lippiatt B. C. Multidisciplinary life cycle metrics, and tools for green buildings, Integr. Environ. Assess. Manag. 5 (2009) 390-398,

https://setac.onlinelibrary.wiley.com/doi/abs/10.1897/IEAM_2 008-069.1

[23] Kibert C. j. Sustainable Construction: Green Building Design and Delivery, 3rd ed., John Wiley \& Sons Inc., Hoboken, New Jersey, USA, 2012.

https://scholar.google.com/scholar?q=+author:C.\%20j.\%20Kibert

[24] Laustsen J. Energy Efficiency Requirements in Building Codes, Energy Efficiency Policies for New Buildings, International Energy Agency (IEA), Paris, 2008 https://www.iea.org/publications/freepublications/publication/ Building_Codes.pdf

[25] Dwaikat L, Kherun A. 2016. "Green Buildings Cost Premium: A Review of Empirical Evidence." Energy and Buildings 110: 396-403.

https://www.sciencedirect.com/science/article/pii/S037877881 5303856

[26] Cole R. J. Rating systems for sustainability, in V. Loftness, D. Haase (Eds.), Sustain. Built Environ. 1st ed., Springer, New York, 2013, pp. 464-477, https://link.springer.com/referencework/10.1007\%2F978-14614-5828-9

[27] Burnett J, Chau C, Lee W. Green buildings: how green the label? HKIE Trans. 12 (2005) 1-8, https://www.tandfonline.com/doi/abs/10.1080/1023697X.2005 .10668014

[28] U.S. Green Building, Council, U.S. green building council, Leadership. Energy Environ. Des. (2014), https://new.usgbc.org/leed

[29] BREEAM, Building Research Establishment Environmental Assessment Methodology, 2016. www.breeam.org.

[30] Madew R. The Dollars and Sense of Green Buildings. A Report for the Green Building Council of Australia, Green Building Council of Australia, https://www.gbca.org.au/resources/dollars-and-sense-ofgreen-buildings-2006-building-the-business-case-for-greenc/gbca.asp?sectionId=304

[31] Torcellini P, Pless S, Deru M, Griffith B, Long N, Judkoff R. Lessons Learned from Case Studies of Six High-Performance Buildings (Technical Report NREL/TP-550-37542), National Renewable Energy Laboratory (NREL), 2006, https://www.nrel.gov/docs/fy06osti/37542.pdf

[32] Ries, R. Bilec, M. M. Needy, K. L. Gokhan, N. M. The economic benefits of green buildings: a comprehensive case study, Eng. Econ. 51 (2006) 259-295, https://www.tandfonline.com/doi/full/10.1080/001379106008 65469

[33] Juaidi A, Montoya FG, Ibrik Imad H, Manzano-Agugliaro F. An overview of renewable energy potential in Palestine. Renew Sustain Energy Rev 2016; 65:943-60. https://www.sciencedirect.com/science/article/pii/S136403211 630380X?via\%3Dihub

[34] Alatawneh B, Germana M, Carrao R. Near Zero Energy House in Palestine: Identification of the Future Challenges 5th International Energy Conference - Palestine (IECP). 27th28th January 2015. Conference Proceeding (pp.47-50).
[35] Haj Hussian M. Courtyard concept: A sustainable strategy for the future housing buildings in Palestine, Conference: Sustainable Architecture \& Urban Development "SAUD 2010"At Amman. July 2010, https:// www.researchgate.net /publication/258237440.

[36] Salameh W. Towards Sustainable Construction Systems of External Walls of Buildings in The West Bank of Palestine (Master Thesis) Nablus, Palestine: An-Najah National University; 2012 https://repository.najah.edu/handle/20.500.11888/7418

[37] Abdel Hadi M. Possibility of developing environmentally friendly residential buildings in Palestinian cities - A study case from the cities of Jenin and Ramallah (Master Thesis), Arabic language Thesis, Nablus, Palestine: An-Najah National University; https://repository.najah.edu/handle/20.500.11888/7449

2013.

[38] Haj Hussian M, Barlet A, Baba M, Semidor C. Evaluation for Environmental Comfort Performance in the Palestinian Schools, PLEA 2016 Los Angeles - 36th International Conference on Passive and Low Energy Architecture. Cities, Buildings, People: Towards Regenerative Environments https://www.researchgate.net/publication/308762434.

[39] Saadeh B, Baba M. Evaluation Study of Green School Buildings in the West Bank, 5th International Energy Conference - Palestine (IECP). 27th-28th January 2015. Conference Proceeding, https:// www.researchgate.net /publication/272783015 https://repository.najah.edu/handle/20.500.11888/7450

[40] Kitaneh R, Alsamamra H, Aljunaidi A. Modeling of wind energy in some areas of Palestine. Energy Convers Manag 2012; $62(0): 64-9$

https://www.sciencedirect.com/science/article/pii/S019689041 2001926?via\%3Dihub

[41] Valipour M. Study of different climatic conditions to assess the role of solar radiation in reference crop evapotranspiration equations. Arch Agron Soil Sci 2015; 61 (5):679-94. https://www.scopus.com/record/display.uri?eid=2-s2.084922236942 \&origin $=$ inward\&txGid $=84 d 16 a 63 d 39 f 494291 \mathrm{c}$ $503 \mathrm{~d} 51 \mathrm{~b} 7 \mathrm{a} 3 \mathrm{fc} 9$

[42] Palestine Higher Green Building Council, 2013. Green buildings Guidelines - State of Palestine. First ed. Ramallah, Palestine: Palestinian Engineers Association https://www.paleng.org/wpcontent/uploads/2015/10/pgbc manual.pdf

[43] Applied Research Institute of Jerusalem, (2003). Climatic zoning for energy efficient buildings in the Palestinian territories (the West Bank and Gaza). ARIJ, Jerusalem. https://www.arij.org/files/admin/2003/2003\%20climatic\%20z oning $\% 20$ for $\% 20$ energy $\% 20$ efficient $\% 20$ buildings $\% 20$ in $\% 20$ the \%20PT.pdf

[44] Yaseen B. Renewable energy applications in Palestine. Palestinian energy and environment research center (pec)energy authority, technical department, Palestine. In: Proceedings of the 2nd international conference for the Palestinian environment, Palestine; 2009.

[45] Hasan A. Wind energy in the west bank and Gaza strip. RE 1992; 2 (6):637-9 https://www.scopus.com/record/display.uri?eid=2-s2.00027007396\&origin $=$ inward\&txGid $=$ ea3ad44777ca6187069ff ed0f0c16a6a 
[46] Abu Hamed T, Flamm H, Azraq M. Re in the Palestinian territories: opportunities and challenges. Renew Sustain $\begin{array}{llll}\text { Energy } & \text { Rev } & 2012 ; & 16\end{array}$ https://www.sciencedirect.com/science/article/pii/S136403211 1004898?via\%3Dihub

[47] Abualkhair A. Electricity sector in the Palestinian territories: which priorities for development and peace? Energy Policy 2007; 35 (4):2209-30.

https://www.sciencedirect.com/science/article/pii/S030142150 6002795?via\%3Dihub

[48] Daud A-K, Ismail M. Design of isolated hybrid systems minimizing costs and pollutant emissions. RE 2012; 44:21524

https://www.sciencedirect.com/science/article/pii/S096014811 2000225?via\%3Dihub

[49] Ismail M, Moghavvemi M, Mahlia T. Analysis and evaluation of various aspects of solar radiation in the Palestinian territories. Energy Convers Manag 2013; 73:57-68. https://www.sciencedirect.com/science/article/pii/S019689041 3002239?via\%3Dihub

[50] Sancho J, Riesco J, Jimenez C, Sanchez de Cos M, Montero J, Lopez M. Atlas de radiacion solar en españa utilizando datos del saf de clima de eumetsat, Agencia Estatal de Meteorologia (AEMET), Ministerio de Agricultura, Alimentacion y Medio Ambiente del Gobierno de España.

[51] Morrison GL, Litvak A, Condensed solar radiation database for Australia, Tech rep, University of New South Wales; 1999. http://users.tpg.com.au/t_design/papers/tmy99.pdf

[52] Hernandez-Escobedo Q, Rodriguez-Garcia E, Saldana-Flores R, FernandezGarcia A, Manzano-Agugliaro F. Solar energy resource assessment in Mexican states along the Gulf of Mexico. Renew Sustain Energy Rev 2015; 43 (0):216-38. https://www.sciencedirect.com/science/article/pii/S136403211 4008429?via\%3Dihub
[53] Abu-Hafeetha MF. Planning for solar energy as an energy option for Palestine (Master Thesis) Nablus, Palestine: AnNajah National University; 2009.

[54] RIWAQ Records of Historic Buildings in Palestine, File I, Arabic language book, Palestine, 2006.

[55] Palestinian Engineers Association, Palestine Higher Green Building Council, 2013 https://www.paleng.org/?p=417

[56] Palestinian Code, Energy Efficient building Code, Ministry of Local Government, 2004 https://www.paleng.org/?p=1729

[57] Palestinian Museum, Ramallah, Palestine https://palmuseum.wordpress.com/tag/leed/

[58] The A. M. Qattan Foundation, Ramallah, Palestine http://qattanfoundation.org/en/qattan/about/building

[59] SHTAYYA Green building, Nablus, Palestine, URL: https://www.dropbox.com/s/erzq94hswxesbyu/Synopsis\%20$\% 20$ SHTAYYA $\% 20$ Building.pdf?dl=0\& fbclid=IwAR2GFqGj J3UfkaATrtCsFKOTn8UP2hXzfXIpFFXd60PScgfmSnh6OjV5eU

[60] ShamsArd Design Studio, Ramallah, Palestine, https://www.shamsard.com/architecture

[61] Palestinian Central Bureau of Statistics, General Population, Housing, and Establishment Census, 2017 RamallahPalestine.http://www.pcbs.gov.ps/Downloads/book2383.pdf

[62] Hamdan "Folk architecture of Palestine" Albireh: Family reviving association, Arabic language book, 1996.

[63] AlKhatib K. Zero Net Energy Buildings: Identification of the Future Challenges 5th International Energy Conference Palestine (IECP). 27th-28th January 2015. Conference Proceeding (pp.126-128). 